\title{
Chapter 11 \\ Real-World Laboratories Initiated \\ by Practitioner Stakeholders \\ for Sustainable Land \\ Management-Characteristics \\ and Challenges Using the Example of Energieavantgarde Anhalt
}

\section{Helga Kanning, Bianca Richter-Harm, Babette Scurrell, and Özgür Yildiz}

\begin{abstract}
Real-world laboratories have gained substantially in importance as a format in sustainability and transformation research in recent years in Germany. This increase in significance is associated with the expectation of fostering and experimentally investigating transformations towards sustainability under real-world conditions in a bid to gain knowledge of their dynamics, to identify characteristics of successful transformation processes, and to be able to transfer this knowledge to other cases. Real-world laboratories are usually managed by a scientific partner, enabling use to be made of established procedures and methods in areas such as knowledge integration. Where responsibility for coordinating real-world laboratories lies with practitioner stakeholders, there is promising potential for their deployment. However, it also gives rise to situations, processes and challenges that are new to all parties involved and that have yet to be explored. In principle, experimental approaches that are characteristic of real-world laboratories are not new in the field of sustainable land management and spatial development. However, they are not traditionally alluded to as the real-world
\end{abstract}

For reasons of readability and simplicity, no use is made of the masculine and feminine form when referring to people or job titles in this publication. However, all genders are implied at all times.

H. Kanning $(\varangle) \cdot$ B. Richter-Harm

Sustainify GmbH, Institut für Nachhaltige Forschung, Bildung, Innovation, Große Düwelstr. 28,

30171 Hannover, Germany

e-mail: kanning@sustainify.de

B. Richter-Harm

e-mail: post@ sustainify.de

B. Scurrell

Schefferweg 2, 12249 Berlin, Germany

e-mail: babette.scurell@bund.net

Ö. Yildiz

Department of Environmental Economics, Technische Universität Berlin, Straße des 17. Juni, 10623 Berlin, Germany

e-mail: oezguer.yildiz@campus.tu-berlin.de

T. Weith et al. (eds.), Sustainable Land Management in a European Context,

Human-Environment Interactions 8, https://doi.org/10.1007/978-3-030-50841-8_11 
laboratory format. The two desiderata above provide the starting point for the present article. The aim of this article is to classify and reflect on the possibilities generated by real-world laboratories that have been initiated by practitioner stakeholders. A prime example of such real-world laboratories are those developed by Energieavantgarde Anhalt. This registered association wishes to contribute to sustainable land management in the context of the energy transition in rural areas, featuring small and medium-sized towns. A comparative analysis of these real-world laboratories is conducted using core characteristics from the scientific debate on real-world laboratories. As a result, the insight gained from this analysis can be used for future development and research.

Keywords Regional energy transition - Real-world laboratories as a whole, within a project $\cdot$ Practitioner stakeholder's initiative $\cdot$ Participation $\cdot$ Co-design, Co-production

\subsection{Introduction}

Real-world laboratories are gaining importance in the field of sustainable land management and spatial development (see, for example, Augenstein et al. 2016; Hahne and Kegler 2016). In Germany, the discussion on these innovative formats was primarily triggered by the flagship report by the German Advisory Council on Global Change (WBGU) "World in Transition: A Social Contract for Sustainability" (WBGU 2011). In its report, WBGU recommends a new kind of interaction between politics, society, science and the economy (ibid.: 26). In this context, transdisciplinary and transformative sustainability research is encouraged (Schneidewind and Singer-Brodowski 2013: 2015) and, in particular, the format of real-world laboratories promoted (Schneidewind 2014).

The popularity of real-world laboratories has increased dramatically recently in Germany, due not least to the initiation of several support programmes at the federal and state level. ${ }^{1}$ As such, both the variety of publications and publication density are developing dynamically and at a disproportionately high rate, as pointed out clearly in the analysis by Schäpke et al. (2018a). At the same time, a debate has emerged that is controversial to some extent. While some see little new in the real-world laboratory format, others pin their hopes on the (potentially) innovative power of real-world laboratories (Beecroft and Parodi 2016: 4). In other words, the debate on real-world laboratories and the potential they have for social transformations and

\footnotetext{
${ }^{1}$ The state government of Baden-Württemberg in particular was quick to embrace the WBGU recommendations, establishing a "Science for Sustainability" group of experts (MWK 2013) and initiating two support programmes for real-world laboratories (BaWü Labs); for an overview, see: https://mwk.baden-wuerttemberg.de/de/forschung/forschungspolitik/wissenschaftfuer-nachhaltigkeit/reallabore/ (last accessed on 16 July 2019). The Federal Ministry of Education and Research (BMBF) also promotes real-world laboratories, for example in the context of the "City of the Future" funding initiative (Schmidt 2017), addressing not only universities in the process, but also communities or municipalities as practitioner stakeholders.
} 
for transformation research has only just begun. ${ }^{2}$ Real-world laboratories are "in their infancy" (Beecroft and Parodi 2016: 4), and a detailed methodological and theoretical concept has yet to be developed (Grunwald 2016: 204f). Although it can be assumed that real-world laboratories initiated by practitioner stakeholders have high deployment potential on account of the practical approach they take, they have attracted little attention in the scientific debate to date (Engels and Rogge 2018; Menny et al. 2018).

Real-world experiments are generally considered to be the core of the real-world laboratory approach (Schäpke et al. 2017: 3). This idea is not new in the field of sustainable land management. In fact, the approach of experimentally investigating social change processes at the urban level goes back to the sociological Chicago School of the 1920s (Gross et al. 2005: 65ff; Schneidewind 2014: 3). In land management, for example, there are many projects and model projects of an experimental nature that are not, however, termed real-world laboratories. Examples include the International Building Exhibitions (IBA), state and national flower shows, the regional structural aid measures in North Rhine-Westphalia called the REGIONALE, and various regional development processes in the context of European regional assistance (see De Flander et al. 2014: 285; Hohn et al. 2014). As yet, the experience gained in these measures is largely detached from the real-world laboratory debate, meaning that a great deal of research is needed to bring together these aspects (De Flander et al. 2014: 285).

These two desiderata provide the starting point for the present article. The objective is to integrate into the scientific debate real-world laboratories that have been initiated and coordinated by practitioner stakeholders for the purpose of sustainable land management, and to reflect on the possibilities and limitations of those approaches. In the process, questions that have not been addressed in the scientific discussion to date are of importance: What challenges arise when real-world laboratories are initiated by practitioner stakeholders? Are those challenges similar to those arising in real-world laboratories designed by scientists? How do they differ? What opportunities do they offer, and what added value can be expected from the real-world laboratory format? To answer these questions, Sect. 11.2 provides an account of the real-world laboratories initiated by the Energieavantgarde Anhalt (EAA) association, which include the urban laboratories undertaken within the joint research project "The re-productive town" ${ }^{3}$ funded by the Federal Ministry of Education and Research (BMBF). The core characteristics of real-world laboratories are then identified from the scientific literature. These characteristics provide the theoretical basis for discussing the special features of real-world laboratories that have been initiated by practitioner stakeholders (Sect. 11.3). This discussion is based not

\footnotetext{
${ }^{2}$ Concerning classification in transdisciplinary research and transformation research, see, e.g. Wittmayer and Hölscher (2016), Rogga et al. (2018).

${ }^{3}$ The project entitled "The re-productive town. Changing towns for achieving the energy and sustainability transition" [original in German: Die re-produktive Stadt. Die Stadt verändern, um die Energieund Nachhaltigkeitswende zu schaffen] receives BMBF funding under the FONA/Social-Ecological Research: "Sustainable Transformation of Urban Areas" funding line from August 2016 to July 2019; see https://re-produktive-stadt.energieavantgarde.de.
} 
only on the experience gained from the BMBF-funded project "The re-productive town", but also on insights from three workshops held with EAA members and other interested participants (business representatives, especially from the utilities sector; representatives from local government and politics and from science) in 2017. The article concludes with a critical analysis and an outlook for future developments (Sect. 11.4).

\subsection{Real-World Laboratories Initiated by the Practitioner Stakeholder Energieavantgarde Anhalt e.V.}

Energieavantgarde Anhalt (EAA) is an association that acts as a network of stakeholders comprising civil activists, municipalities and rural districts, companies and other institutions in the Anhalt-Bitterfeld-Wittenberg region. This network is committed to accelerate the energy transition in the region in cooperation with national and European partners. The approach was developed in the context of the profound, multiple socio-economic transformation processes that pose huge challenges to towns and regions, such as the closure of businesses and the loss of livelihoods, demographic change, and the energy transition. The direct impact of these processes is very much apparent in the Anhalt-Bitterfeld-Wittenberg region: high cost pressure relating to infrastructure, a sharp fall in property prices, the demolition of entire neighbourhoods. A wide range of technical, economic and socio-cultural innovations are needed to meet the challenges associated with these developments in this region dominated by lignite mining and the chemical industry. These innovations radically change land uses, creating new decentralised, interconnected and energy systems based on renewables, as well as new urban-rural relations. In the process, EAA places particular emphasis on the regionalisation of energy production and energy use and on sector coupling. To achieve this, developments in the area of prosumer models and demand-side management measures should encourage not only resource efficiency, but also system-supporting, flexible energy consumption behaviour, and enable as many citizens as possible to participate in the regional energy transition through regional added value and democratic processes.

Since there is no ready guidance on how to meet these challenges and since a wide range of individual issues need to be resolved, the association calls this largescale regional experiment the "Anhalt Real-World Laboratory" (www.energieavant garde.de). In this laboratory, partners engaged as practitioners in the region and scientists join forces to design a variety of sub-laboratories and experimental setups. With this in mind, the association brings together within its framework not only local authorities, public utility companies and technology companies from the renewables sector, but also civil society interest groups. The projects in the region initiated by EAA are generally based on the experience and issues raised by association members within their everyday operations and on collaboration with research institutions in other projects. In their role as project initiators and project coordinators in the region, 
members of the association explicitly represent the interests of the association and of the regional stakeholders it represents. As a result, the focus is on searching for workable approaches for promoting sustainable development by using renewable energies and achieving high resource efficiency. Considering contributions from the current scientific real-world laboratory debate, this regional institution could also be characterised as a "real-world laboratory as a whole" [own translation] (Beecroft et al. 2018: 80) where various transdisciplinary sustainability projects are implemented.

The joint research project entitled "The re-productive town", which has received BMBF funding for three years, is one of the outcomes of EAA's activities in the Anhalt region. Initiated by EAA, the research alliance comprises EAA and Bitterfeld-Wolfen Town Council as its practice partners, and Brandenburg University of Technology (BTU) Cottbus-Senftenberg/Chair of Urban Technical Infrastructure, the Fraunhofer Institute for Microstructure of Materials and Systems (IMWS) and inter 3 Institute for Resource Management as its science partners. The project is accompanied scientifically by sustainify Institut für nachhaltige Forschung, Bildung, Innovation. In the research project, the town of Bitterfeld-Wolfen is taken as an example of the urban planning challenges associated with transformation. This town seems to be particularly suited to develop and test new approaches for social-ecological urban development. The starting point of the project is the energy sector, from which inroads are made into agriculture and forestry, architecture and building services, industry and finance, citizenry, the urban economy and the urban landscape. Possibilities are systematically sought to consider unexploited resources such as brownfield sites, sun, wind and green waste as well as secondary resources such as waste heat and refuse as a starting point for something new. These innovations are then reutilised for the benefit of the town and its inhabitants or the processes that generate them are directly changed. Conceptually, the approach refers back to the concept of (re)productivity proposed by Biesecker and Hofmeister (2006). According to this concept, (urban) production and consumption processes must be designed in such a way that the town maintains or even improves its material/energy and economic/social reproductive capability in order to remain sustainable or to ensure its long-term survival. The aim is to use the systematic improvement of the material/energy and economic/social reproductive capability of Bitterfeld-Wolfen Town to develop a blueprint for a possible transformation path for a new, yet very common type of town as a result of territorial reforms: an extensive, medium-sized, polycentric town that can be expected to offer new starting points for energy and sustainability transition and, as a result, new townscapes and urban landscapes.

Urban laboratories are a core format. Urban laboratories are site-specific participatory and communication platforms that map ongoing local transformation processes and enable broad participation. They provide the experimental basis for developing, negotiating and implementing into urban design solutions for the use of secondary resources in urban spaces in cooperation with the population, companies and the administration. This is undertaken in work phases of living labs or real-world laboratories such as co-design, co-creation, co-exploration, coexperimentation/testing and co-evaluation steps. More specifically, four urban laboratories representing neighbourhoods typical of medium-sized towns were selected 
in consideration of characteristics such as resource potentials and stakeholder constellations. These neighbourhoods are

- A central, inner-city area, characterised by a combination of brownfield and industrial areas (neighbourhood type - inner-city brownfield in a central location: "Am Plan" urban laboratory)

- A detached housing estate, including listed buildings, that faces extensive changes in ownership structure (neighbourhood type-existing housing estate with a garden city character: "Gartenstadt" urban laboratory)

- A new housing estate with detached houses and multiple dwellings on an urban open space (neighbourhood type—new residential area: "Krondorfer Wiesen" urban laboratory)

- A multiple dwelling demolition area characterised by industrial housing construction as well as demographic and socio-economic challenges (neighbourhood type-industrial prefabricated large housing estate: "Wohnkomplex 4/4" urban laboratory).

\subsection{A Comparison of Core Characteristics}

As outlined in the introduction, there is as yet no uniform theoretical and detailed methodological concept of real-world laboratories (Grunwald 2016: 204f), and therefore no uniform definition either. However, several scientific institutions are currently performing further groundwork, especially also in the context of research in support of the real-world laboratories (BaWü Labs) funded in Baden-Württemberg. ${ }^{4}$ On the international arena, there are also a multitude of other approaches that are similar to the real-world laboratory format or that were used as its basis. These include living labs, sustainable living labs and urban transition/living labs (for a comparative overview, see Schäpke et al. 2017: 28ff; Schäpke et al. 2018b). Furthermore, an almost inflationary (and simultaneously unspecific) use is currently being made of the term "lab" in other fields.

According to a definition originally introduced by Schneidewind (2014), a realworld laboratory generally describes "... a societal context in which researchers carry out interventions in the sense of 'real-life experiments' in order to learn about social dynamics and processes" [own translation] (Schneidewind 2014: 3). Real-life experiments are considered to be the core of the real-world laboratory approach (Schäpke et al. 2017: 3 with reference to WBGU 2014, 2016; Schneidewind 2014; De Flander et al. 2014; MWK 2013; Wagner and Grunwald 2015). The idea is to transfer the term "laboratory", as used in the natural sciences context, to the analysis of social and

\footnotetext{
${ }^{4}$ These include, in particular, the Wuppertal Institute (WI), the Institute for Technology Assessment and Systems Analysis (ITAS) at the Karlsruhe Institute of Technology (KIT), the Institute for Social-Ecological Research (ISOE), as well as Leuphana University and the University of Basel, especially in the context of research in support of BaWü Labs. BaWü Labs are supported by two teams of researchers: (1) the "ForReal" team (WI, ISOE, Leuphana University), (2) BF-Uni Basel (University of Basel).
} 
political processes in concrete social contexts (Schäpke et al. 2017: 4). According to the definition coined by Gross et al. (2005), a hybrid form of the experiment is associated with this term, ranging between the production and application of knowledge and situation-specific and controlled boundary conditions (Schneidewind 2014: 2). Conceptually, real-world laboratories therefore build on the 'experimental turn' in the social, economic and sustainability sciences, and are similar to other transdisciplinary and participatory research approaches such as transdisciplinary case studies, participatory action research, fieldwork, intervention research or transition research (Schäpke et al. 2017: 4, referring in each case to prominent representatives of the approaches named).

In the scientific landscape, the concept of the real-world laboratory is therefore easily expandable and currently formative. In practice, however, the term is rejected by some because it evokes associations that experiments are being performed on the participants (Grießhammer and Brohmann 2015: 22). The term "urban laboratory" proved to be useful for work in the "The re-productive town" project. This is because the term is used in the field of urban development, albeit with diverse and different meanings, such as for educational institutions with an experimental laboratory character.

In order to shed light on what characterises real-world laboratories that have been initiated and largely shaped by practitioner stakeholders, we refer below to the core characteristics listed by Parodi et al. (2016): research orientation, normativity, transdisciplinarity, transformativity, civil society orientation/participation, long-term nature and laboratory character (see Table 11.1). These core characteristics largely correspond to or overlap with characterisations proposed by other authors such as WBGU (2016), Schäpke et al. (2017), Defila and Di Giulio (2018a). We add another core feature - continuous processes of reflection and learning with regard to one's own research practice and social effect; these characterise the research process (e.g. Schäpke et al. 2018b; Schneidewind and Singer-Brodowski 2015).

Based on these core characteristics, an outline is given below of how real-world laboratories initiated and coordinated by EAA can be characterised, whether and how they differ from those real-world laboratories that are initiated and coordinated by stakeholders from science, whether they face challenges and, if so, what those challenges are. The definition of the relevant core characteristics is given in Table 11.1 .

\subsubsection{Regarding Research Orientation}

In the Anhalt Real-World Laboratory 'as a whole', the EAA association offers interested researchers the region's problems concerning energy design, energy policy and energy management, some of which have already been formulated and structured; its contacts with regional practitioner stakeholders; and its expertise in the development of a sustainable regional energy system for transdisciplinary research. In this sense, EAA serves as an institution for sustainability and transformation research; 
application-oriented research is explicitly mentioned in the association's statutory objectives. However, whether or to what extent these institutions for real-world laboratories must always have a scientific character is not deemed absolutely necessary in the previous discussion. Instead, the association focuses primarily on practical orientation and on the search for practicable approaches towards sustainable development in its areas of interest; in the process, analytical work and the consideration of internal scientific interests are accepted as prerequisites for joint research and

Table 11.1 A comparison of the core characteristics and real-world laboratories undertaken by Energieavantgarde Anhalt (authors' compilation)

\begin{tabular}{|c|c|c|c|}
\hline Core characteristics & $\begin{array}{l}\text { Real-world laboratories } \\
\ldots\end{array}$ & $\begin{array}{l}\text { Anhalt real-world } \\
\text { laboratory as a whole }\end{array}$ & $\begin{array}{l}\text { Urban laboratories in } \\
\text { the project "The } \\
\text { re-productive town" }\end{array}$ \\
\hline $\begin{array}{l}\text { Research } \\
\text { orientation }\end{array}$ & $\begin{array}{l}\ldots \text { act as scientific } \\
\text { facilities in } \\
\text { sustainability and } \\
\text { transformation } \\
\text { research }^{1}\end{array}$ & $\begin{array}{l}\text { Not necessarily, } \\
\text { focuses on practical } \\
\text { orientation }\end{array}$ & $\begin{array}{l}\checkmark \\
\text { Research closely } \\
\text { oriented to practice }\end{array}$ \\
\hline Normativity & $\begin{array}{l}\text {... are oriented towards } \\
\text { the principles of } \\
\text { sustainable } \\
\text { development }^{1}\end{array}$ & $\checkmark$ & $\checkmark$ \\
\hline Transdisciplinarity & $\begin{array}{l}\text {... function in a } \\
\text { transdisciplinary way } \\
\text { They directly connect } \\
\text { science and society } \\
\text { (practitioner } \\
\text { stakeholders) and use } \\
\text { forms and methods of } \\
\text { transdisciplinary } \\
\text { research in their } \\
\text { experiments }\end{array}$ & $\checkmark$ & $\checkmark$ \\
\hline Transformativity & $\begin{array}{l}\ldots \text { conduct } \\
\text { transformative } \\
\text { research. They are } \\
\text { hybrid undertakings } \\
\text { that aim to } \\
\text { concurrently achieve } \\
\text { scientific findings and } \\
\text { social design. They } \\
\text { facilitate sustainability } \\
\text { research and } \\
\text { simultaneously make } \\
\text { experimental } \\
\text { contributions to } \\
\text { sustainable } \\
\text { development }{ }^{1}\end{array}$ & $\checkmark$ & $\checkmark$ \\
\hline
\end{tabular}


Table 11.1 (continued)

\begin{tabular}{|c|c|c|c|}
\hline Core characteristics & $\begin{array}{l}\text { Real-world laboratories } \\
\ldots\end{array}$ & $\begin{array}{l}\text { Anhalt real-world } \\
\text { laboratory as a whole }\end{array}$ & $\begin{array}{l}\text { Urban laboratories in } \\
\text { the project "The } \\
\text { re-productive town" }\end{array}$ \\
\hline $\begin{array}{l}\text { Civil society } \\
\text { orientation, } \\
\text { participation }^{3}\end{array}$ & $\begin{array}{l}\text {... integrate citizens } \\
\text { and/or civil society in } \\
\text { particular as strong } \\
\text { partners and } \\
\text { decision-makers into } \\
\text { their work from the } \\
\text { beginning } \\
\text {.. embrace } \\
\text { participation, from } \\
\text { information and } \\
\text { consultation to } \\
\text { cooperation and } \\
\text { empowerment, and } \\
\text { develop their } \\
\text { transdisciplinary } \\
\text { experiments in } \\
\text { co-design }{ }^{1}\end{array}$ & $\begin{array}{l}\checkmark \\
\text { But opposite direction } \\
\text { of activity: drive comes } \\
\text { from civil society, } \\
\text { which involves science }\end{array}$ & $\begin{array}{l}\checkmark \\
\text { But opposite direction } \\
\text { of activity: drive comes } \\
\text { from civil society, } \\
\text { which involves science }\end{array}$ \\
\hline $\begin{array}{l}\text { Long-term } \\
\text { nature }\end{array}$ & $\begin{array}{l}\ldots \text { are long-term } \\
\text { research facilities } \\
\text { spanning (many) } \\
\text { decades }^{1}\end{array}$ & $\checkmark$ & - \\
\hline $\begin{array}{l}\text { Laboratory } \\
\text { character }\end{array}$ & $\begin{array}{l}\ldots \text { are laboratories. } \\
\text { They are a } \\
\text { transdisciplinary } \\
\text { infrastructure in order } \\
\text { to ensure the best and } \\
\text { most stable conditions } \\
\text { possible for } \\
\text { experimental research } \\
\text { and observation in } \\
\text { complex real-world } \\
\text { contexts }\end{array}$ & $\checkmark$ & $\checkmark$ \\
\hline $\begin{array}{l}\text { Continuous } \\
\text { reflection and } \\
\text { learning } \\
\text { process }^{4}\end{array}$ & $\begin{array}{l}\text { Research in real-world } \\
\text { laboratories is devised } \\
\text { and understood as a } \\
\text { continuous reflection } \\
\text { and learning process } \\
\text { with regard to one's } \\
\text { own research practice } \\
\text { and social effect }\end{array}$ & $\checkmark$ & $\checkmark$ \\
\hline
\end{tabular}

${ }^{1}$ Own translation of Parodi et al. (2016: 16)

${ }^{2}$ Own translation of Parodi et al. (2016: 16f)

${ }^{3}$ Own addition to description of characteristics

${ }^{4}$ Own addition based on Schäpke et al. (2017: 5), Schneidewind and Singer-Brodowski (2015) 
development activities. This principle of strong practical orientation can be adapted accordingly to current circumstances and needs at the specific project level.

One example are the urban laboratories in the BMBF joint research project entitled "The re-productive town"; these feature an explicit research orientation. The research questions were defined jointly by the scientific partners and the practice partners (co-design); they are accessible for scientific analysis and for practical changes for transformation towards sustainability.

\subsubsection{Regarding Normativity}

The normative orientation towards sustainability is one of the association's implicit statutory objectives and, as such, of the Anhalt Real-World Laboratory. This orientation is specified in the association's statutes on objectives such as to contribute to environmental protection and climate action, and the objective to conserve the natural basis of life.

In urban laboratories, the normative assumptions, principles and objectives regarding the reference to the concept of re-productivity by Biesecker and Hofmeister (2006) are made explicit. In this context, the following insight was gained from ongoing work: scientific partners proceed in accordance with elaborated sustainability concepts in real-world laboratories, and it would be helpful for companies, civil society organisations, other institutions and local authorities to use or develop concrete tools in the practical implementation of real-world laboratories. Examples that would make the integrative concept of sustainability tangible for practitioners in the process include environmental protection concepts, corporate social responsibility standards, a local climate action plan, the European Energy Award and other quality management systems. It may also be helpful in this context to adapt for practical use scientific-theoretical sustainability approaches such as the concept of re-productivity in an intermediate step, and to prepare such approaches for practical implementation in the real world (Yildiz et al. 2012).

\subsubsection{Regarding Transformativity}

In the Anhalt Real-World Laboratory, the EAA association focuses primarily on the shaping of society in terms of the energy transition, mainly by way of local experimental contributions. To do this, EAA draws on findings resulting from sustainability research. The work of EEA backs two aspects of real-world laboratories: first, the Anhalt Real-World Laboratory sees itself as an element of various niche experiments embedded in structuring processes somewhere between the niche level and the regime level. Second, in line with its objective, the work performed by the association should help further develop transformative sciences by portraying and 
investigating the abstract format of transformation in the real-world laboratory as a physical environment.

Owing to their origins, urban laboratories are likewise primarily practiceoriented. Potential changes in the practices of resource utilisation by municipal stakeholders play a key role in the selection of neighbourhoods, and therefore also in the constitution of the problem, the institutions and people involved, and the methods and intensity of participation. This framework also yields a wide range of options for sustainability research and scientific evidence (e.g. the methodological operationalisation of the characteristics of re-productivity in criteria for assessing technical and socio-economic solutions) (Schön et al. 2013).

The strong practical orientation in the EAA real-world laboratories necessitates a careful reflection and evaluation of the approaches taken so as to be able to make statements on the effect of interventions and on the course of transformation processes in real-world laboratories. The small scale and reach of the measures that can be implemented concerning sustainable urban development generally make it difficult to formulate transferable results, which is currently being hotly discussed as a general phenomenon of real-world laboratories. ${ }^{5}$ One cannot help but suspect that a specific contribution to resource efficiency or a viable use of renewable energies in a certain neighbourhood arises more by accident than by design due to a certain constellation of problems and stakeholders. It is then impossible to repeat such a success at other locations. The result is that strong practical orientation represents a restriction, especially for scientific partners. Then again, precisely these small-scale changes can occur and be documented in the Anhalt Real-World Laboratory. These are the small steps that represent the details of social transformation, which is ultimately of greater significance from a practical point of view.

\subsubsection{Regarding Civil Society Orientation, Participation}

This characteristic exhibits the biggest difference between the state of the scientific discussion and the approaches taken by the EAA real-world laboratories. The drive to initiate the Anhalt Real-World Laboratory came from civil society, which involved scientists in the project as strong partners. The initiative for the BMBF joint research project and its urban laboratories also came from EAA. As such, the direction of activity is opposite to the characteristic portrayed in the literature. The idea for a scientifically supported, experimental transformation of the regional energy system arose from the realisation that the special constellation of stakeholders seeking change and the decisive issue of regional energy supply involving the broader shaping and economic participation of the population became apparent as an opportunity for innovative action. Although science, lobby institutions and financial backers were then involved in the subsequent establishment of the Anhalt Real-World Laboratory at the

${ }^{5}$ Concerning this, see also, e.g. Krohn et al. (2017) and www.td-academy.de (last accessed on 16 July 2019). 
very beginning, the format can be described as a laboratory initiated by practitioner stakeholders, because:

- Practitioner stakeholders from the Anhalt region raised the issue of the regional energy transition, and had already addressed this issue with their own commitment using the resources available to them for more than three years,

- The establishment of the real-world laboratory was only conceivable and feasible due to the active work of key regional stakeholders seeking to change the existing system, and

- It was only possible to address additional practitioner stakeholders with success because of the trusting relationships among regional stakeholders that had been in existence for several years.

Against this backdrop, an important finding that is a compelling case for the establishment and long-term operation of real-world laboratories by practitioner stakeholders is the fact that it takes a long time to establish successful participatory constellations. This longer-term option is missing in urban laboratories (see the long-term nature criterion). To achieve effective cooperation in the transformation of society, all stakeholders must also act proactively so as to position their issues and other concerns. After all, a form of cooperation that always expects the drive and organisation to come from the same partner will soon show signs of fatigue. It is clear that the involvement of local stakeholders remains a challenge, even if the real-world laboratory is initiated by practice partners. Even if a region has activists who are interested in transformative research, this does not mean that all of the stakeholders needed to tackle a specific issue are willing to get involved. At best, the initiating practice partner will be powerful, influential and well networked, enabling it to organise the constructive participation of the necessary stakeholders.

\subsubsection{Regarding the Long-Term Nature and Laboratory Character}

The Anhalt Real-World Laboratory is designed for the long term. The association seeks to establish transdisciplinary infrastructure with adequate physical and personnel resources (criterion laboratory character) to be able to ensure the best, most stable possible conditions for experimental research and observation in complex real-world contexts (see Parodi et al. 2016). In contrast, urban laboratories are based on a three-year time frame and are project-related, despite ideally desiring their longer-term and autonomous establishment.

The availability of sufficient resources is a prerequisite for this. However, the non-profit association has very limited resources. One possibility would be to raise funds by providing services, but this would imply a change of role to that of a market economy stakeholder like an energy agency, planning office or consulting agency. However, if EAA represents its own business interests, it runs the risk of losing 
credibility with regard to the handling of sensitive data. This is likely to affect the trust required to acquire regional cooperation partners for transformative research, and the quasi-public role of mediating between possibly competing partners could only be played to a very limited extent in the best case (Yildiz and Schön 2014).

As a result, in order to maintain transdisciplinary infrastructure in the long run, other ways of obtaining sustainable funding must be found by EAA in this specific case and by other practitioner stakeholders seeking to establish real-world laboratories. One option could be a system of mixed financing, comprising continuous funding from state and local resources, together with the acquisition of external funding for research to ensure the independence and impartiality of the real-world laboratory. In this way, the Anhalt Real-World Laboratory could be stabilised as an independent sponsor of transformative research and regional development, akin to an (economic) development agency. With regard to ensuring sustainable infrastructure, the challenge is principally to ensure continuous work processes. This is not possible in the case of project funding alone. After all, funding shortfalls will inevitably occur between a funding project and the next funding projects, ideally following straight on from the first. Unlike research institutions, which are equipped with basic funding, practitioner stakeholders are particularly affected by such shortfalls. Moreover, subsequent funding is uncertain, and there are limitations to the capability of the content to tie in with previous funding, due to the fact that support programmes are usually themed. Besides the (political) will to establish experimental spaces and to actively co-create them, the funding issue therefore becomes a key issue for the establishment of longer-term, viable infrastructures for real-world laboratories (see Kanning and Scurrell 2018).

\subsubsection{Regarding Continuous Processes of Reflection and Learning}

To assess the processes of reflection and learning, emphasis is placed below on the level of interdisciplinary and transdisciplinary cooperation (Singer-Brodowski et al. 2018) as well as the associated role of accompanying research (Defila and Di Giulio 2018b).

When it established the Anhalt Real-World Laboratory, EAA already made provision for accompanying research. The discussions about the topic proved to be difficult. This was because partners with previous experience in transdisciplinary research expected to be closely involved in the real-world laboratory, while the majority of partners assumed that traditional observational research would be conducted. The accompanying research was thus established in the context of a Ph.D. project at the Berlin Social Science Center (WZB), financed by the real-world laboratory. In the light of the findings on relations between researchers, accompanying researchers and financial backers presented in the meantime by Defila and Di Giulio (2018b), it is now possible to make a more detailed assessment of this issue. 
The existing accompanying research in the Anhalt Real-World Laboratory is indeed geared towards producing knowledge on the processes that take place in the real-world laboratory. According to Defila and Di Giulio (2018b), however, the relation to individual projects in the real-world laboratory can be described as a relation to the "object of research" that is characterised by dependence and an unequal distribution of power. This relation to the object is very much apparent in the real-world laboratory. The strong substantive involvement of the association's main financial backer gives it access to information about the individual projects. What is more, in addition to the geographical proximity of the accompanying research to the association's sponsors (both from outside the region), the financial backer's interests are close to those of the research institution, namely the effectiveness of energy policy and the national recognition of achievements. As such, the tensions described by Defila and Di Giulio (2018b) do not occur in the sponsor's relation to accompanying research, but there are tensions in both their relations to regional stakeholders. There is a realisation that the establishment of the Anhalt Real-World Laboratory, driven by practitioner stakeholders, could well have benefited from accompaniment experienced in transdisciplinary research in order to cope with integrating the different bases and forms of knowledge.

In the BMBF research project entitled "The re-productive town", within which urban laboratories are initiated and developed, this was achieved by contracting out support in the experience process, the knowledge process and the process of transferring results - although it was not possible to describe this that clearly at the time of the application. The knowledge of experienced transdisciplinary researchers is necessary to integrate knowledge bases from practice and science; to produce transferable knowledge; and, not least, to ensure the continuous self-reflection of different, sometimes changing roles in the transdisciplinary learning process. Ideally, such knowledge should be involved as early as at the stage of conceptually designing real-world laboratories. In this case, scientific accompaniment by a neutral moderator such as sustainify $\mathrm{GmbH}$ proved to be successful in the joint research project, ensuring the integration of different bases and forms of knowledge as well as the self-reflection of the practice and scientific partners involved. This insight is consistent with the recommendations already made by Parodi et al. to ensure "co-created accompaniment that supports real-world laboratories in a cooperative, advisory manner" [own translation] (2018: 179).

\subsection{A Summary Critical Appraisal and Outlook}

Real-world laboratories are a relatively young and yet highly diverse format that is interpreted and shaped in a strongly divergent manner by practitioners in some cases. The debate has only just begun and is still being shaped. In principle, many of the characteristics of real-world laboratories discussed are not new for sustainable land management, such as the development of common problem definitions and solutions (co-design, co-production), as is often the case especially in informal processes of 
sustainable urban and regional developments. What is more, knowledge on participation in planning processes also virtually serves as a role model for real-world laboratories (Eckart et al. 2018: 131ff; Kanning 2018). As such, real-world laboratory formats are compatible with sustainable land management, and also offer added value. Especially real-world laboratory formats that are initiated and coordinated by practitioner stakeholders offer specific implementation potential and, at the same time, are faced with particular challenges.

In our opinion, the direct and explicit integration of objectives for practice and research associated with the real-world laboratory format (Defila and Di Giulio 2018c: 40) represents particular added value over common participatory land management processes. In real-world laboratories, all of the stakeholders involved, whether practitioners or scientists, are considered to be "researchers" [own translation] (Eckart et al. 2018: 105f) who jointly define the solution to the problem and produce new knowledge (co-design, co-production), integrating different specialist disciplines as well as science and practice. In contrast to the planning and development approaches established in land management, an extended self-conception can be identified that could help bridge the oft-criticised gap between theory and practice (e.g. Lamker et al. 2017). In real-world laboratories, the transformation approach is oriented to radical innovations and change processes towards sustainability in a much more proactive manner than is often the case to date in sustainable urban and regional development processes (see Heyen et al. 2018: 26). Where the principle of sustainable development is reflected critically and understood integratively in correspondence with the state of scientific knowledge in real-world laboratories, this goes beyond the current prevailing understanding of sustainability in land management. The latter focuses primarily on the safeguarding or creation of ecological qualities, and pays little attention to the original core of the idea of sustainability, i.e. the transformation of social, economic action in a social-ecological direction (see Kanning 2005; Hofmeister 2014). In this connection, it would also be necessary to include in the discussion the generally inherent, unquestioned concept of material growth (see Fröhlich and Gerhard 2017: 28ff). As such, the real-world laboratory format-in line with the design currently featuring strongly in the scientific discourse-could help establish experimental spaces for radical innovations in which the various areas of expertise in transformation and planning (science) are brought together for sustainable land management and, ideally, linked to educational objectives (see Beecroft et al. 2018: 78).

Real-world laboratories that are initiated and coordinated by practitioner stakeholders also offer special deployment potential due their practical approach, and at the same time face special challenges. On that point, a number of insights and hypotheses can be summarised from EAA's experiences and discussions for further scientific discourse and practical development:

Practitioner stakeholders must satisfy various conditions and have certain skills to be able to initiate real-world laboratories. Among other things, they must be capable of organising a research alliance; making their results publicly accessible; and participating in scientific discourse. They must also either have their own financial resources for conducting research or at least have a strong position in the relevant 
stakeholder network, enabling them to generate the financial resources needed to operate a real-world laboratory.

Scientific and practitioner stakeholders often face the same challenges when establishing the research process, because the interests of many stakeholders must be accommodated when it comes to complex transformation processes. There is always a need to formulate issues in a practically relevant as well as scientifically interesting and challenging manner at the constituent stage of the project, irrespective of the real-world laboratory initiator's institutional background. It is only the weighting of the practical and scientific relevance that may vary to a certain extent. The good position of a research-affine practitioner stakeholder may make it easier to develop stable stakeholder networks for the purpose of achieving cooperation among the relevant practitioner stakeholders, but the various aspects of effective participation must be borne in mind nonetheless. On the other hand, practitioner stakeholders find it particularly challenging to find scientific partners from several disciplines who go along with a joint problem definition and who are not only interested in obtaining data or conducting purely scientific experiments. In addition, social or economic practitioners who have initiated real-world laboratories tend to be challenged more by the need for experience in methods of knowledge integration and modelling for the purpose of transferring results. One solution for this may be to seek support from experienced transdisciplinary researchers and to involve these experts in the conceptual design stage of the real-world laboratory.

Based on these findings, real-world laboratories led by practitioner stakeholders offer particularly favourable conditions when they are backed by local authorities or public bodies. Strong local governments have excellent links; they know the stakeholders' interests; they have experience in planning participatory processes, which can be largely transferred to real-world laboratories (Eckart et al. 2018: 131ff); they can perpetuate transdisciplinary research, ensuring continuity and, on this basis, learning processes. However, small and medium-sized towns, and towns undergoing socio-economic structural change that feature disproportionate demographics are often under financial supervision and rarely have the human resources capacity to be able to undertake the research that is urgently required for their strategic realignment. Such local authorities therefore tend to be unable to support real-world laboratories, which means that they are only rarely able to incorporate their particular problems in research projects. Consequently, support structures are required to make real-world laboratories accessible to all local authority types.

Against this backdrop, real-world laboratories should not only be financed by research funding in the future, but at least in equal parts by structural support from the relevant ministries (e.g. the Ministry of Energy and/or the Ministry for Economic Affairs). After all, besides producing effects in research and science, real-world laboratories (are supposed to) actively drive forward transformation towards a sustainable society (see Kanning and Scurrell 2018).

Several recent changes in science and structural policy will improve the conditions for real-world laboratories initiated by practitioner stakeholders in future. These include a greater shift towards citizen science, including its transformation towards to more complex civic research beyond mere data collection. Citizens are more 
frequently involved in the formulation of research issues, and the definition of criteria for data collection and analysis. Various institutions besides universities and research institutes give citizens the possibility to participate in research. The "Green Paper Citizen Sciences Strategy 2020 for Germany”, published in 2016, provides guidance on activating citizen science for the purpose of transformation that is appreciated, acknowledged and embraced by society and science alike (Bonn et al. 2016: 25). From the perspective of practitioner stakeholders, it is important to create stronger links in future between citizen science formats, ranging from data collection to active codesign and active co-production (ibid.), to the original real-world laboratory format developed by science, creating synergies. In addition, since the 2017 Bundestag elections at the latest, greater attention is being paid in structural policy to the development of rural regions and their small and medium-sized towns. If such attention can also be translated into supporting measures for the sustainable development of rural areas, there will be new financial leeway for real-world laboratories, which can be established and used as experimental spaces for sustainable land management.

\section{References}

Augenstein, K., Haake, H., Palzkill, A., Schneidewind, U., Singer-Brodowski, M., Stelzer, F., \& Wanner, M. (2016). Von der Stadt zum urbanen Reallabor - eine Einführung am Beispiel des Reallabors Wuppertal. In U. Hahne \& H. Kegler (Eds.), Resilienz. Stadt und Region: Reallabore der resilienzorientierten Transformation (Vol. 1, pp. 167-195). Frankfurt am Main, New York: PL Academic Research (Stadtentwicklung Urban development).

Beecroft, R., \& Parodi, O. (2016). Reallabore als Orte der Nachhaltigkeitsforschung und Transformation. Einführung in den Schwerpunkt. Technikfolgenabschätzung-Theorie und Praxis, 25(3), $4-8$.

Beecroft, R., Trenks, H., Rhodius, R., Benighaus, C., \& Parodi, O. (2018). Reallabore als Rahmen transformativer und transdisziplinärer Forschung: Ziele und Designprinzipien. In A. Di Giulio \& R. Defila (Eds.), Transdisziplinär und transformativ forschen - Eine Methodensammlung (pp. 75100). Wiesbaden.

Biesecker, A., \& Hofmeister, S. (2006). Die Neuerfindung des Ökonomischen. Ein (re)produktionstheoretischer Beitrag zur Sozial-ökologischen Forschung. München.

Bonn, A., Richter, A., Vohland, K., Pettibone, L., Brandt, M., Feldmann, R., et al. (2016). Green Paper Citizen Science Strategy 2020 for Germany. Helmholtz-Zentrum für Umweltforschung (UFZ), Deutsches Zentrum für integrative Biodiversitätsforschung (iDiv) Halle-JenaLeipzig, Leipzig, Museum für Naturkunde Berlin, Leibniz-Institut für Evolutions- und Biodiversitätsforschung (MfN), Berlin-Brandenburgisches Institut für Biodiversitätsforschung (BBIB). Berlin.

De Flander, K., Hahne, U., Kegler, H., Lang, D., Lucas, R., Schneidewind, U., et al. (2014). Resilience and real-life laboratories as key concepts for urban transformation research. Resilienz und Reallabore als Schlüsselkonzepte urbaner Transformationsforschung. Zwölf Thesen. GAIAEcological Perspectives for Science and Society, 23(3), 284-286.

Defila, R., \& Di Giulio, A. (2018a). Reallabore als Quelle für die Methodik transdisziplinären und transformativen Forschens - eine Einführung. In R. Defila, \& A. Di Giulio (Eds.), Transdisziplinär und transformativ forschen (pp. 9-35). Eine Methodensammlung. Wiesbaden.

Defila, R., \& Di Giulio, A. (2018b). What is it good for? Reflecting and systematizing accompanying research to research programs. GAIA-Ecological Perspectives for Science and Society, 27(S1), 97-104. 
Defila, R., \& Di Giulio, A. (2018c). Partizipative Wissenserzeugung und Wissenschaftlichkeit - ein methodologischer Beitrag. In R. Defila, \& Di Giulio, A. (Eds.), Transdisziplinär und transformativ forschen (pp. 39-67). Eine Methodensammlung. Wiesbaden.

Eckart, J., Ley, A., Häußler, E., \& Erl, T. (2018). Leitfragen für die Gestaltung von Partizipationsprozessen in Reallaboren. In A. Di Giulio \& R. Defila (Ed.), Transdisziplinär und transformativ forschen: Eine Methodensammlung (pp. 105-135). Wiesbaden.

Engels, F., \& Rogge, J. C. (2018). Tensions and trade-offs in real-world laboratories-the participants' perspective. GAIA-Ecological Perspectives for Science and Society, 27(S1), 28-31.

Fröhlich, K., \& Gerhard, U. (2017). Wissensbasierte Stadtentwicklung - ein Erfolgskonzept auch für Nachhaltigkeit? Einblicke in die Entwicklung der Heidelberger Südstadt aus Reallaborperspektive. In Deutsche Akademie für Landeskunde e.V. und Leibniz Institut für Länderkunde (Eds.), Reallabore als Forschungsformat nachhaltiger Stadtentwicklung, Leipzig, Berichte (Vol. 91, Issue 1, pp. 13-33). Geographie und Landeskunde (BGL).

Grießhammer, R., \& Brohmann, B. (2015). Wie Transformationen und gesellschaftliche Innovationen gelingen können. UFOPLAN-Vorhaben-FKZ 371211103. (Ed.: Umweltbundesamt). Dessau-Roßlau.

Gross, M., Hoffmann-Riem, H., \& Krohn, W. (2005). Realexperimente. Ökologische Gestaltungsprozesse in der Wissensgesellschaft. Bielefeld.

Grunwald, A. (2016). Nachhaltigkeit verstehen: Arbeiten an der Bedeutung nachhaltiger Entwicklung. München.

Hahne, U., \& Kegler, H. (Ed.). (2016). Resilienz. Stadt und Region: Reallabore der resilienzorientierten Transformation (p. 1). Frankfurt am Main, New York: PL Academic Research (Stadtentwicklung Urban development).

Heyen, D. A., Brohmann, B., Libbe, J., Riechel, R., \& Trapp, J. H. (2018). Stand der Transformationsforschung unter besonderer Berücksichtigung der kommunalen Ebene. Paper within the "Vom Stadtumbau zur städtischen Transformationsstrategie project" as part of the "Experimenteller Wohnungs- und Städtebau" (ExWoSt) research programme. Sine loco.

Hofmeister, S. (2014). Das Leitbild Nachhaltigkeit - Anforderungen an die Raum- und Umweltplanung. In: H. Heinrichs \& G. Michelsen (Eds.), Nachhaltigkeitswissenschaften (pp. 304-320). Berlin, Heidelberg.

Hohn, U., Kemming, H., \& Reimer, M. (Eds.). (2014). Formate der Innovation in der Stadt- und Regionalentwicklung. Reflexionen aus Planungstheorie und Planungspraxis, Detmold $=$ Reihe Metropolis und Region des Stadt- und regionalwissenschaftlichen Forschungsnetzwerks Ruhr (SURF) (p. 13).

Kanning, H. (2005). Brücken zwischen Ökologie und Ökonomie - Umweltplanerisches und ökonomisches Wissen für ein nachhaltiges regionales Wirtschaften. München.

Kanning, H. (2018). Reallabore aus planerischer Perspektive. sustainify Arbeits- und Diskussionspapier 3|2018, sustainify Institut für nachhaltige Forschung, Bildung, Innovation. Hannover.

Kanning, H., \& Scurrell, B. (2018). Reallabore der Praxisakteure - Merkmale und methodische Herausforderungen. Sustainify Arbeits- und Diskussionspapier 1|2018, sustainify Institut für nachhaltige Forschung, Bildung, Innovation. Hannover.

Krohn, W., Grunwald, A., \& Ukowitz, M. (2017). Transdisziplinäre Forschung revisited: Erkenntnisinteresse, Forschungsgegenstände, Wissensform und Methodologie. GAIA-Ecological Perspectives for Science and Society, 26(4), 341-347.

Lamker, C., Peer, C., \& Sondermann, M. (2017). Zum Verhältnis von Planungswissenschaft und -praxis. Nachrichten der ARL, 47(1), 10-13.

Menny, M., Palgan, Y. V., \& McCormick, K. (2018). Urban living labs and the role of users in co-creation. GAIA—Ecological Perspectives for Science and Society, 27(S1), 68-77.

MWK-Ministerium für Wissenschaft, Forschung und Kunst Baden-Württemberg (Ed.). (2013). Wissenschaft für Nachhaltigkeit. Herausforderung und Chance für das baden-württembergische Wissenschaftssystem. Stuttgart. 
Parodi, O., Beecroft, R., Albiez, M., Quint, A., Seebacher, A., Tamm, K., \& Waitz, C. (2016). Von "Aktionsforschung" bis "Zielkonflikte"-Schlüsselbegriffe der Reallaborforschung. Technikfolgenabschätzung - Theorie und Praxis, 25(3), 9-18.

Parodi, O., Ley, A., Fokdal, J., \& Seebacher, A. (2018). Empfehlungen für die Förderung und Weiterentwicklung von Reallaboren: Erkenntnisse aus der Arbeit der BaWü-Labs. GAIA-Ecological Perspectives for Science and Society, 27(S1), 178-179.

Rogga, S., Zscheischler, J., \& Gaasch, N. (2018). How much of the real-world laboratory is hidden in current transdisciplinary research? GAIA-Ecological Perspectives for Science and Society, 27(S1), 18-22.

Schäpke, N., et al. (2017). Reallabore im Kontext transformativer Forschung. Ansatzpunkte zur Konzeption und Einbettung in den internationalen Forschungsstand. ETSR Discussion papers in Transdisciplinary Sustainability Research, Leuphana Universität, Lüneburg.

Schäpke, N., Bergmann, M., Stelzer, F., \& Lang, D. J. (2018a). Labs in the real world: Advancing transdisciplinary research and sustainability transformation: Mapping the field and emerging lines of inquiry. GAIA-Ecological Perspectives for Science and Society, 27(S1), 8-11.

Schäpke, N., Stelzer, F., Caniglia, G., Bergmann, M., Wanner, M., Singer-Brodowski, M., et al. (2018b). Jointly experimenting for transformation? Shaping real-world laboratories by comparing them. GAIA-Ecological Perspectives for Science and Society, 27(S1), 85-96.

Schmidt, A. (2017). Zukunftsstadt. Forschung für klimaresiliente, sozial-ökologisch gerechte und lebenswerte Städte. GAIA-Ecological Perspectives for Science and Society, 26(4), 355-356.

Schneidewind, U. (2014). Urbane Reallabore - ein Blick in die aktuelle Forschungswerkstatt. Planung neu denken (pnd) online, 10(3), 1-7.

Schneidewind, U., \& Singer-Brodowski, M. (2013). Transformative Wissenschaft: Klimawandel im deutschen Wissenschafts-und Hochschulsystem. Marburg.

Schneidewind, U., \& Singer-Brodowski, M. (2015). Vom experimentellen Lernen zum transformativen Experimentieren: Reallabore als Katalysator für eine lernende Gesellschaft auf dem Weg zu einer Nachhaltigen Entwicklung. Zeitschrift für Wirtschafts- und Unternehmensethik (ZfWU), 16(1), 10-23.

Schön, S., Biesecker, A., Hofmeister, S., \& Scurrell, B. (2013). (Re)Produktives Wirtschaften im Dialog mit der Praxis. In Netzwerk Vorsorgendes Wirtschaften (Ed.), Wege Vorsorgenden Wirtschaftens (2nd ed., pp. 159-200). Marburg.

Singer-Brodowski, M., Beecroft, R., \& Parodi, O. (2018). Learning in real-world laboratories: A systematic impulse for discussion. GAIA-Ecological Perspectives for Science and Society, 27(S1), 23-27.

Wagner, F., \& Grunwald, A. (2015). Reallabore als Forschungs- und Transformationsinstrument: Die Quadratur des hermeneutischen Zirkels. GAIA-Ecological Perspectives for Science and Society, 24(1), 26-31.

WBGU-German Advisory Council on Global Change. (2011). World in transition: A social contract for sustainability. Summary for policy makers. Berlin.

WBGU-German Advisory Council on Global Change. (2014). Special report climate protection as a world citizen movement. Berlin.

WBGU-German Advisory Council on Global Change. (2016). Humanity on the move: Unlocking the transformative power of cities. Berlin.

Wittmayer, J. M., \& Hölscher, K. (2016). Transformation research: Goals, contents, methods. Workshop Report. Drift 216.

Yildiz, Ö., Drießen, F., Pobloth, S., \& Schön, S. (2012). Re-Produktionsketten als Ansatz koevolutionärer Regionalwirtschaft. Ökologisches Wirtschaften, 27(S1), 30-36. 
Open Access This chapter is licensed under the terms of the Creative Commons Attribution 4.0 International License (http://creativecommons.org/licenses/by/4.0/), which permits use, sharing, adaptation, distribution and reproduction in any medium or format, as long as you give appropriate credit to the original author(s) and the source, provide a link to the Creative Commons license and indicate if changes were made.

The images or other third party material in this chapter are included in the chapter's Creative Commons license, unless indicated otherwise in a credit line to the material. If material is not included in the chapter's Creative Commons license and your intended use is not permitted by statutory regulation or exceeds the permitted use, you will need to obtain permission directly from the copyright holder.

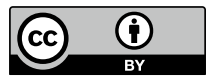

